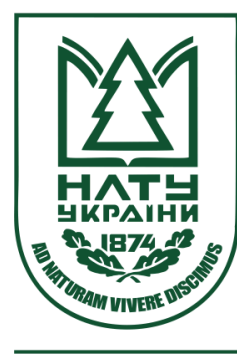

Науковий вісник НЛТУ України Scientific Bulletin of UNFU

http://nv.nltu.edu.ua

https://doi.org/10.15421/40290416

$@ \bowtie$ Correspondence author

Article received 17.02.2019 p.

Article accepted 25.04.2019 p.

I. S. Stetsiv

УДК 657.1:658:4

Irina.S.Stetsiv@Ipnu.ua

I. C. Стеців

Національний університет "Львівська політехніка", м. Львів, Украйна

\title{
ТРИВИМІРНА МОДЕЛЬ КЛАСИФІКАЦІЇ ВИТРАТ СУБ'ЄКТІВ ЕКОНОМІКИ ЯК ЗАСІБ АДАПТАЦІЇ НАУКОВО ОБГРУНТОВАНОГО ПІДХОДУ ДО АВТОМАТИЗАЦІЇ УПРАВЛІНСЬКИХ ПРОЦЕСІВ
}

\begin{abstract}
Досліджено підходи вчених до класифікації витрат суб'єктів економіки та, на основі проведеного дослідження, впорядковано класифікацію витрат із застосуванням науково обгрунтованого підходу. На базі запропонованої категоріальної класифікації та із застосуванням OLAP технології розроблено тривимірну матричну модель класифікації витрат. Обгрунтовано, що наведену вище тривимірну матричну модель класифікації витрат можна застосовувати для будь-якого суб'єкта господарювання з урахуванням галузевих особливостей та конкретних цілей управління. Визначено перевагу цієї моделі, яка полягає в узгодженості всіх видів витрат та класифікаційних ознак бухгалтерського та управлінського обліку, а також у встановленні взаємозв'язків та взаємозалежностей між ними. Зокрема, за допомогою OLAP технологій (online analytical processing аналітичнє оброблення в реальному часі), будь-яку суму витрат можна охарактеризувати за приналежністю до певної статті витрат, місця виникнення, визначити прямі чи непрямі витрати, постійні чи змінні, а також розрахувати вплив їх зміни на собівартість певного об'єкта калькулювання. Доведено, що застосування запропонованої багатовимірної матричної моделі класифікації витрат у зазначених параметрах дає змогу скоротити тривалість оброблення інформації, підвищує оперативність прийняття управлінських рішень та сприяє покращенню системи управління витратами.

Ключові слова: категоріальна класифікація; OLAP технології; управління витратами; елементи витрат; статті калькулю-
\end{abstract} вання.

Вступ. У сучасних умовах науково-технічний прогрес досягнув глобальних масштабів та охопив практично всі сфери людської діяльності, зокрема управління. Ефективне функціонування суб'єктів економіки стало залежним від рівня автоматизації управлінських процесів, проте досягнення інформаційних технологій у цьому напрямі не характеризуються значними успіхами. Зокрема вдосконалення потребують процеси автоматизації управління витратами, як важливої ланки управління підприємством загалом. Важливість застосування класифікації витрат під час розроблення новітніх інформаційних технологій для автоматизації процесу управління витратами підкреслюють багато вчених. Проте розроблення та впровадження такого рівня інформаційних технологій потребує адаптації теоретичних положень управління витратами до алгоритмів роботи комп'ютерних програм. Учені наголошують на необхідності використання науково обгрунтованої класифікації під час розроблення спеціального програмного забезпечення, що дасть змогу всебічного охоплення інформації щодо поведінки витрат для прийняття ефективних управлінських рішень (Bernard et al., 2016, pp. 99-113; Stotskyi, 1934, pp. 290-319; Tkachenko, 2003, pp. 46-60), що потребує подальшого ії впорядкування.

Проблема ускладнюється тим, що у практичній ді- яльності переважної більшості суб'єктів економіки управління витратами не застосовується наукова класифікація витрат. Зокрема йдеться про відсутність групування витрат з урахуванням просторової та часової характеристики, а саме за місцями виникнення та календарними періодами. Оокрім цього, розподіл витрат на прямі та непрямі, а також на постійні та змінні в більшості з них здійснюється необгрунтовано. Управління витратами виконується на рівні підприємства загалом із групування витрат за економічним змістом та статтями калькулювання. Такий підхід зменшує можливості дослідження поведінки витрат та значно погіршує якість управління ними.

Мета роботи - комплексне дослідження підходів вчених до класифікації витрат суб'єктів економіки, впорядкування класифікації витрат із застосуванням науково обгрунтованого підходу та розроблення вдосконаленої моделі класифікації витрат, адаптивної до процесів автоматизації на будь-якому суб'єкті господарювання з урахуванням галузевих особливостей та конкретних цілей управління.

В основу дослідження покладено принципи діалектичного методу пізнання явищ і процесів, у межах якого використано абстрагування, аналогію, аналіз, індукцію, дедукцію, синтез, графічний метод, проектування,

\section{Інформація про авторів:}

Стеців Ірина Семенівна, канд. екон. наук, ст. викладач, кафедра економіки підприємства та інвестицій. Email: Irina.S.Stetsiv@Ipnu.ua

Цитування за ДСтУ: Стеців І. С. Тривимірна модель класифікації витрат суб'єктів економіки як засіб адаптації науково обґрунтованого підходу до автоматизації управлінських процесів. Науковий вісник НЛтУ України. 2019, т. 29 , № 4. С. 75-81.

Citation APA: Stetsiv, I. S. (2019). Three-dimensional matrix classification model of expenses of economic entities as a means of adapting a scientifically grounded approach to automation of managerial processes. Scientific Bulletin of UNFU, 29(4), 75-81. https://doi.org/10.15421/40290416 
моделювання.

Викладення основного матеріалу. Перші спроби класифікації витрат зробив математик Лука Пачолі наприкінці XV ст., котрий розподілив витрати обігу на три групи стосовно підприємства, товару, господарського процесу (Pacholy, 1995). На початку XIX ст. розпочалось активне обговорення проблеми класифікації витрат. Одним із перших у радянській літературі наукову класифікацію витрат створив В. І. Стоцький. Він розподілив витрати на основні й накладні, прямі та непрямі, постійні та змінні (Palyi, 1987, p. 57). Проте потреба достеменного вивчення усіх ракурсів витрат спонукала до пошуків нових класифікаційних ознак, які б розкривали зміст і значення окремих витрат. Аналіз літературних джерел показав, що на сьогодні вчені описали понад 40 класифікаційних ознак групування витрат, що повинно сприяти різнобічному вивченню витрат. Проте таке розмаїття класифікаційних ознак тільки ускладнює процес пізнання, оскільки існуюча на сьогодні класифікація перенасичена дублюванням їх суті та змісту.

Отже, виникає потребу впорядкування існуючої класифікації витрат та адаптації їі до потреб управління. Для вирішення цієї проблеми ми дослідили підходи вчених до класифікації витрат, на основі якого всі існуючі види витрат згруповано відповідно до загальнотеоретичних засад формування класифікацій.

Значний вплив на теорію і практику класифікації мають праці індійського вченого Ш. Р. Ранганатана, який вказує, що за допомогою п'яти основних категорій можна охарактеризувати всі поняття будь-якої галузі знань, а саме: "Індивідуальність", "Матерія", "Енергія", "Простір", "Час". За Ш. Р. Ранганатаном, категорія "Індивідуальність" характеризує предмети, їхні властивості та особливості; категорія "Матерія" означає матеріали, з яких складаються предмети; категорія "Енергія" включає дії, процеси, операції; категорії "Простір" i "Час" визначають відповідно територіальні та хронологічні поняття (Palyha, 2010). На наш погляд, застосування цієї теорії допоможе згрупувати підходи вчених до класифікації витрат за відповідними категоріями і визначити найвагоміші класифікаційні ознаки та види витрат. Для проведення цього дослідження ми вивчали праці вітчизняних та зарубіжних авторів, котрі досліджували це питання.

Для характеристики категорії "Індивідуальність", що iз сукупності досліджуваних витрат ми обрали види витрат, які автори групують за ознакою "оцінка запасів та визначення фінансових результатів" (Atamas, 2009, p. 36; Bondar et al., 2006, p. 249; Butynets, 2012, p. 146; Dreval, 2008 , p. 50). За цією ознакою автори здійснюють розподіл витрат на закінчені та незакінчені, вичерпані й невичерпані, витрати на продукцію і витрати періоду, прямі й непрямі та основні та накладні. Частина авторів під час розподілу витрат на прямі та непрямі називають інші класифікаційні ознаки, а саме: "за способом включення до собівартості" (Erukhymovych, 2003, p. 105; Shtelmakh, 2009, p. 6; Filina, 2008; Horbonos, Cherevko, \& Pavlenchyk, 2010, p. 25; Lyshynenko, 2009, p. 92; Ranhanatan, \& Homolytska, 1970, p. 2), "за способом віднесення на витрати" (Ilina, 2009, p. 445), а також "за способом перенесення вартості на продукцію" (Butynets et al., 2005, p. 14; Teisseyre, Zufferey, \& Słomka, 2019, p. 351). Ми підтримуємо думку переважної більшості авторів і вважаємо доцільним застосування під час розподілу витрат на прямі й непрямі класифікаційної ознаки "за способом включення до собівартості", оскільки ця ознака відображає дійсний зміст та призначення такого розподілу. Отож, під час калькулювання частина витрат включається у собівартість прямим способом, а інша частина - непрямим, а за допомогою певної бази розподілу.

Під час розподілу витрат на основні та накладні автори, окрім наведеної вище класифікаційної ознаки, вказують ще чотири інші ознаки. Зокрема Г. І. Філіна вказує на розподіл зазначених вище витрат за економічним змістом у складі технологічного процесу (Teisseyre, Zufferey, \& Słomka, 2019, p. 351). Автори В. Ф. Палій та Л. О. Штельмах групують ці витрати за відношенням до технічного процесу (Lyshynenko, 2009, p. 92; Ranhanatan, \& Homolytska, 1970, p. 2), а О. В. Лишиленко - за відношенням до виробництва продукції (Pacholy, 1995, p. 25).

На наш погляд, найдоцільнішим $є$ використання класифікаційної ознаки "за характером участі у виробничому процесі", на яку вказують автори І. Л. Срухимович та С. Б. Ільїна (Shtelmakh, 2009, р. 6; Filina, 2008) (рис. 1).

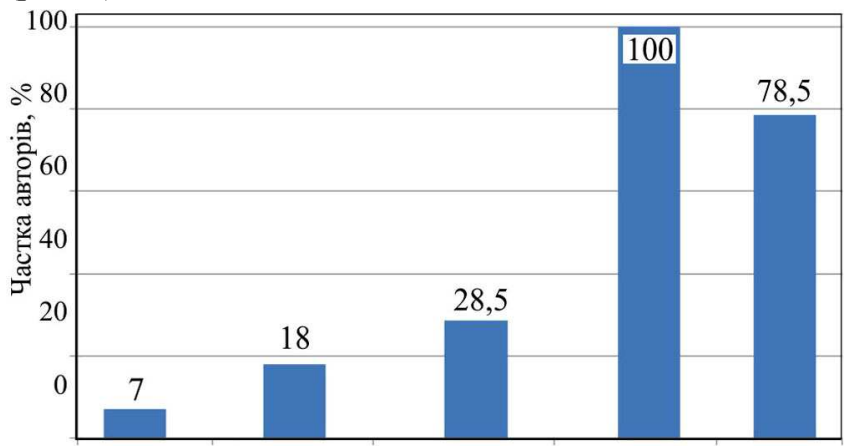

Незавершені, Невичерпані, Витрати періоду, Непрямі, Накладні, завершені вичерпані витрати на продукцію прямі основні Рис. 1. Частина авторів, котрі підтримують розподіл витрат на зазначені види

Аналізуючи дані, отримані в процесі дослідження, що відображені на рис. 1, варто відзначити незначну частку авторів, які погоджуються 3 необхідністю розподілу витрат за ознакою "оцінка запасів та визначення фінансових результатів" на закінчені та незакінчені (7\%), вичерпані та невичерпані (18\%), а також витрат на продукцію та витрат періоду $(28,5 \%)$.

Окрім цього, необхідно звернути увагу на тотожний зміст закінчених та вичерпаних витрат, що свідчать про дублювання видів витрат і потребу скорочення класифікації за принципом відбору найнеобхідніших. Як бачимо 3 рис. 1, однодумність авторів спостерігається тільки стосовно необхідності поділу витрат на прямі та непрямі. Ми погоджуємось із важливістю такого розподілу і вважаємо за доцільне виділити ці види витрат для характеристики категорії "індивідуальність" за ознакою способу включення у собівартість як найдоцільніші.

Групуючи підходи вчених щодо класифікації витрат за категорією "матерія", ми сформували дві підгрупи.

До першої підгрупи належать витрати, які частина авторів класифікують за економічним змістом (Shtelmakh, 2009, p. 6; Horbonos, Cherevko, \& Pavlenchyk, 2010, p. 25; Ilina, 2009, p. 445; Ranhanatan, \& Homolytska, 1970, p. 2). До них відносять витрати за статтями калькулювання та групи елементів витрат.

Деякі автори присвоюють групуванню цих видів витрат інші класифікаційні ознаки. Зокрема Н. М. Тка- 
ченко називає такий розподіл - за видами витрат (Teisseyre, Zufferey, \& Słomka, 2019, p. 351). П. Й. Атамас для характеристики статей калькулювання та елементів витрат подає дві класифікаційні ознаки: "за відношенням до обчислення собівартості" та "за оподаткуванням, складанням фінансової звітності" відповідно (Atamas, 2009, p. 36).

Автор В. Ф. Палій до витрат за економічним змістом відносить витрати засобів праці, предметів праці, живої праці, уречевленої праці, а елементи витрат та статті калькулювання групує за ознакою "здійснення аналітичного обліку" (Lyshynenko, 2009, p. 92). Інші автори елементи витрат та статті калькулювання обирають за ознаку, а видами витрат називають витрати, що входять до складу елементів та статей відповідно (Butynets, 2012, p. 146; Erukhymovych, 2003, p. 105; Filina, 2008; Tapkan et al., 2016, p. 60). На наш погляд, найдоцільнішою назвою ознаки для розподілу витрат на елементи витрат та статті калькулювання $є$ економічний зміст.

Результати проведеного дослідження, що проілюстровано на рис. 2, свідчать про незначну частку авторів, які погоджуються 3 необхідністю розподілу витрат за класифікаційною ознакою "економічний зміст" на витрати засобів праці, предметів праці, живої праці та витрати уречевленої праці - тільки 7 \%. Тому на наш погляд, для характеристики категорії "матерія" достатнім $€$ виділення елементів витрат і статей калькулювання.

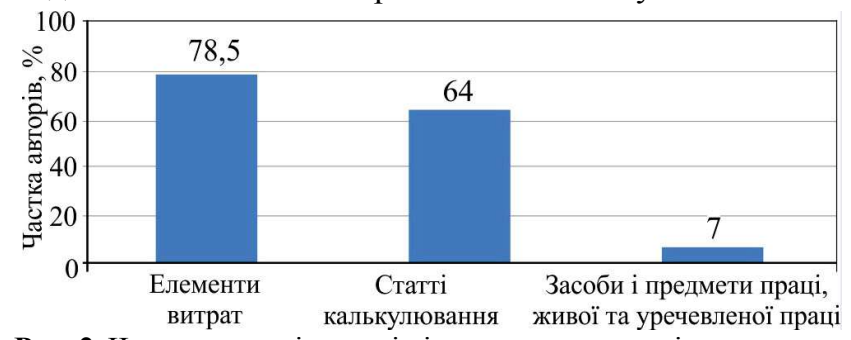

Рис. 2. Частина авторів, котрі підтримують розподіл витрат на зазначені види

Друга група видів витрат, які, на наш погляд, є характерними для категорії "матерія", не має узагальнювальної класифікаційної ознаки, натомість характеризується п'ятьма різними класифікаційними ознаками, причому простежується деяка закономірність: один автор - одна ознака.

Це свідчить про відносно незначну вагомість видів витрат цієї підгрупи у загальній класифікації витрат 3 погляду на їхню підтримку збоку інших авторів, що ілюструє рис. 3 .

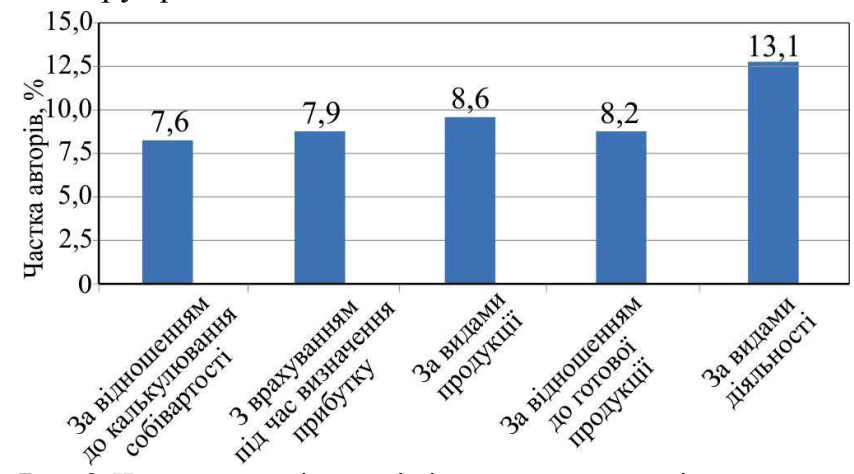

Рис. 3. Частина авторів, котрі підтримують розподіл витрат на зазначені види

Окрім цього, варто відзначити розбіжності у поглядах авторів щодо витрат, які групуються за видами про- дукції. Зокрема Є. М. Палига вказує, що за цією класифікаційною ознакою витрати поділяються на собівартість окремих видів продукції, собівартість окремих замовлень та собівартість реалізації витрати на виробництво (Ilina, 2009, p. 445). Ф. Ф. Бутинець вважає, що вони поділяються на: витрати на вироби, витрати на групи виробів та витрати на замовлення (Butynets et al., 2005, p. 14). Н. М. Ткаченко розподіляе їх на: витрати на вироби, витрати на групи виробів, групи однорідних виробів, типові зразки виробів та валову, товарну, реалізовану продукцію (Teisseyre, Zufferey, \& Słomka, 2019, p. 351).

Як було зазначено раніше, категорія "енергія" відображає дії, процеси, операції, тому під час групування підходів вчених щодо класифікації витрат за цієї категорією обрали класифікаційні ознаки, які належать до певних процесів, на основі чого сформовано дві підгрупи. До першої підгрупи належать витрати, що відносяться до процесу управління.

Деякі автори поділяють витрати за прийняттям управлінських рішень на релевантні та нерелевантні, одноелементні та комплексні, постійні та змінні, маржинальні та середні, а також дійсні та можливі (Atamas, 2009, p. 36; Bondar et al., 2006, p. 249; Butynets, 2012, p. 146; Dreval, 2008, p. 50; Ranhanatan, \& Homolytska, 1970, p. 2).

Під час дослідження ми виявили розбіжності у поглядах вчених щодо формування назв деяких видів витрат, а саме Г. І. Філіна середні витрати називає граничними, а одноелементні - простими (16, р. 60), при цьому розподіл витрат на прості та комплексні здійснює за ступенем економічної однорідності. Тоді як автори О. Ю. Древаль, Є. М. Палига та В. Ф. Палій для цього розподілу застосовують ознаку "за ступенем економічної однорідності" (Erukhymovych, 2003, p. 105; Ilina, 2009, p. 445.; Lyshynenko, 2009, p. 92). Аналогічна ситуація відбувається під час розподілу витрат на постійні та змінні. Більшість авторів розподіляють ці витрати за відношенням до обсягів виробництва (Erukhymovych, 2003, p. 105; Filina, 2008; Ilina, 2009, p. 445; Lyshynenko, 2009, p. 92), I. Л. Єрухимович - за ступенем залежності від кількості виробництва продукції (Shtelmakh, 2009, p. 6).

Ми погоджуємося 3 думкою переважної більшості авторів і вважаємо за доцільне застосування під час розподілу витрат на постійні та змінні класифікаційної ознаки "за відношенням до обсягів виробництва", оскільки ця ознака відображає дійсний зміст і призначення такого розподілу. Для підтвердження наведеного вище варто відзначити, що постійні витрати - це витрати, які не залежать від обсягів виробництва, а змінні - ті, які залежать. Проте зауважимо, що поділ витрат на постійні та змінні є умовним, оскільки одні й ті ж витрати залежно від конкретної ситуації, що складається на підприємстві можуть бути як постійними, так і змінними. Тому з представлених у таблиці видів витрат, на наш погляд, більш обгрунтованим буде розподіл витрат за цією ознакою на умовно-постійні та умовно-змінні.

Як видно 3 рис. 4, значну перевагу з-поміж інших має поділ витрат на постійні та змінні, які, на наш погляд, доцільно обрати для характеристики категорії "Енергія". 


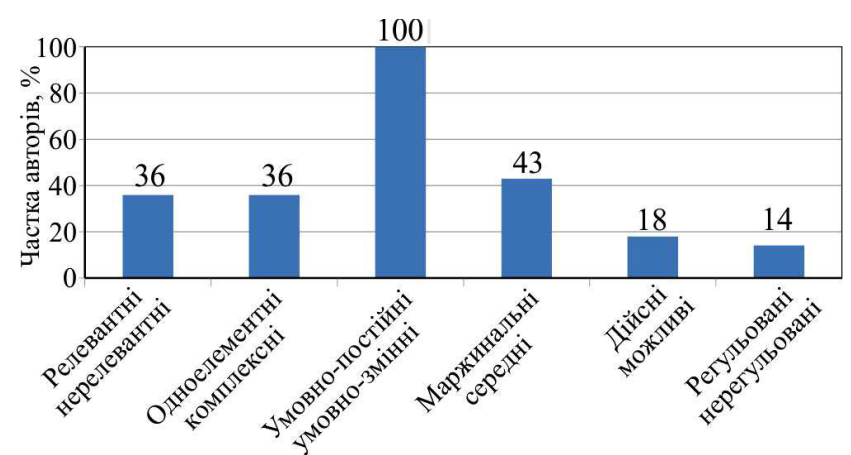

Рис. 4. Частина авторів, котрі підтримують розподіл витрат на зазначені види

До другої підгрупи категорії "енергія" належать витрати, що відносяться до процесу контролю. За можливістю контролю автори розподіляють витрати на контрольовані та неконтрольовані, планові та непланові, продуктивні та непродуктивні (Atamas, 2009, p. 36; Bondar et al., 2006, p. 249; Butynets et al., 2005, p. 15; Dreval, 2008, p. 50; Horbonos, Cherevko, \& Pavlenchyk, 2010, p. 25).

У цій підгрупі також спостерігаємо розбіжності, щодо назв класифікаційних ознак. Зокрема автори Ф. Ф. Бутинець та Г. І. Філіна під час розподілу витрат на продуктивні та непродуктивні виділяють окремі класифікаційні ознаки: "за економічним обгрунтуванням" та "за доцільністю здійснення" відповідно (Butynets et al., 2005, p. 15; Tapkan et al., 2016, p. 60). Ознаку розподілення витрат на планові та непланові С. М. Палига називає "за відношенням до охоплення плануванням" (Ilina, 2009 , р. 445). Оокрім цього, за класифікацією авторів В. Ф. Палія та О. В. Лишиленка одні й ті ж види витрат та їхні класифікаційні ознаки називаються по-різному.

Аналізуючи види витрат цієї підгрупи, варто відзначити низьку частку підтримки такого розподілу іншими авторами: максимально він становить $42 \%$ і належить до розподілу витрат на контрольовані та неконтрольовані, що відображено на рис. 5.

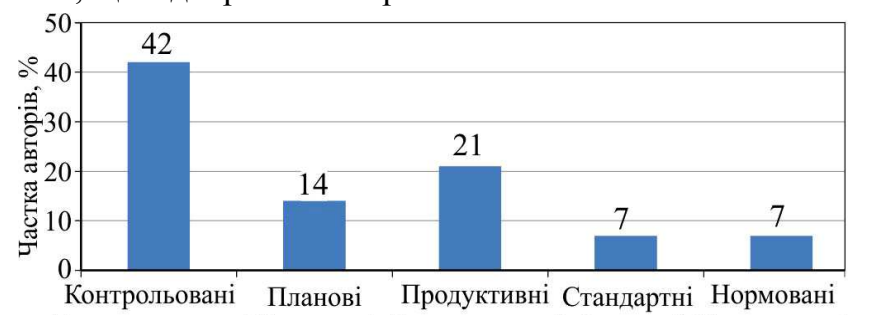

Контрольовані Планові Продуктивні Стандартні Нормовані Рис. 5. Частина авторів, котрі підтримують розподіл витрат на зазначені види

До категорії "простір", на наш погляд, варто віднести види витрат, поділ яких здійснюється за місцями виникнення. Автори, котрі здійснюють розподіл за цією класифікаційною ознакою, виділяють виробничі та невиробничі витрати; витрати основного та допоміжного виробництва, витрати цехів, дільниць та переділів (Ilina, 2009, p. 445), а також витрати виробництва, цехів та дільниць (Butynets et al., 2005, p. 15). Щодо розподілу витрат на виробничі та невиробничі варто відзначити наявність ще трьох класифікаційних ознак, окрім наведеної вище, а саме: за функціями управління (Butynets et al., 2005, p. 15); за роллю у процесі виробництва (Lyshynenko, 2009, p. 92) щодо виникнення впродовж виробничо-комерційного циклу (Shtelmakh, 2009, p. 60).
Оокрім цього, Г. І. Філіна невиробничі витрати називає комерційними (Tapkan et al., 2016, p. 60).

Така диференціація класифікаційних ознак та видів витрат свідчить про відсутність узгодженості у підходах авторів щодо розподілу витрат, оскільки ці ознаки належать до одного виду витрат, а самі види витрат не є взаємодоповнювальними, а мають тотожний міст. Це вкотре підтверджує потребу впорядкування класифікації.

На наш погляд, для характеристики категорії простір поділ витрат на витрати цехів, дільниць та переділів, незважаючи на низький рівень підтримки авторами, що демонструє рис. 6, необхідно виділити 3-поміж інших видів витрат, оскільки вони найбільш точно характеризують ознаку "за місцем виникнення".

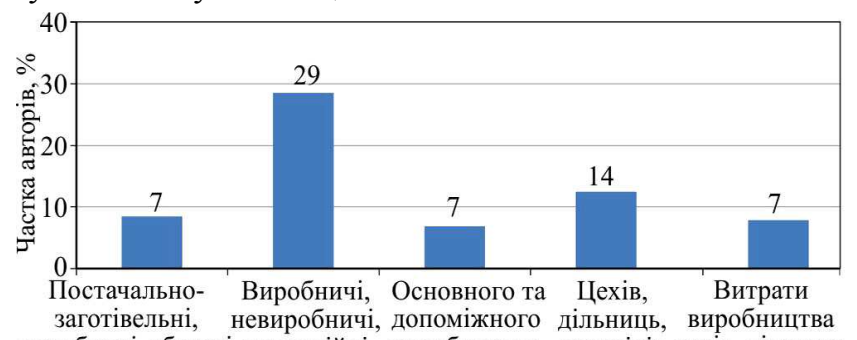
виробничі, збутові комерційні виробництва переділів цехів, дільниць Рис. 6. Частина авторів, котрі підтримують розподіл витрат на зазначені види

Для обгрунтування наведеного вище зазначимо, що місцем виникнення витрат автори називають структурні підрозділи підприємства, за якими організовується планування, нормування та облік витрат виробництва (Lyshynenko, 2009, p. 101), окремі підрозділи, цехи (Davydovych, 2008), робочі місця, ділянки, бригади, відділи підприємства (Butynets, 2012, p. 42).

Із дослідженої сукупності класифікаційних ознак групування витрат для характеристики категорії "час", на наш погляд, можна виділити види витрат за календарними періодами та за періодичністю виникнення.

Автори по-різному здійснюють розподіл витрат щодо класифікаційної ознаки "за календарними періодами". Зокрема С. М. Палига розподіляє витрати на поточні витрати, витрати майбутніх періодів, майбутні та разові (Ilina, 2009, p. 445). В. Ф. Палій подає дві групи видів витрат, які можна віднести до категорії "час", а саме за періодичністю виникнення: щоденні та одноразові, а також за календарними періодами: поточні витрати, майбутніх періодів та витрати минулих періодів (Lyshynenko, 2009, p. 92). Деякі автори за останньою класифікаційною ознакою здійснюють розподіл витрат на поточні та одноразові (Butynets et al., 2005, p. 15; Filina, 2008; Teisseyre, Zufferey, \& Słomka, 2019, p. 15). Варто відзначити тотожний зміст перелічених видів витрат та класифікаційних ознак, що зумовлює потребу їх спрощення.

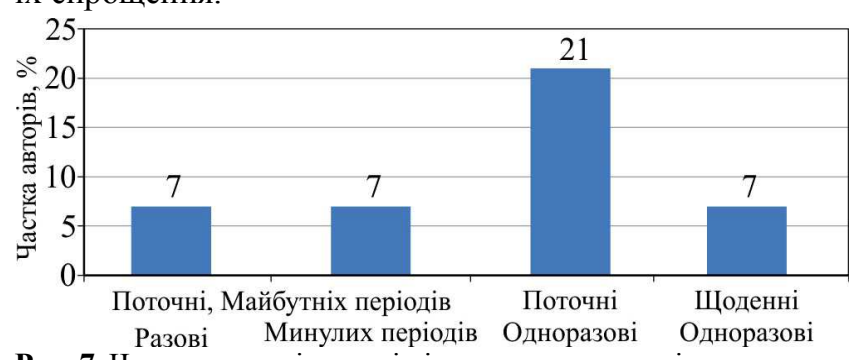

Рис. 7. Частина авторів, котрі підтримують розподіл витрат на зазначені види 
Як видно з рис. 7, автори найбільше підтримали розподіл витрат на поточні та одноразові. Ми погоджуємось 3 необхідністю такого розподілу і вважаємо за доцільне обрати зазначені види витрат для характеристики категорії "час".

Для уникнення тотожностей та впорядкування класифікації за кожною з визначених категорій обрано види витрат, за якими визначено максимальну частку авторів, котрі підтримують потребу розподілу на зазначені види витрат. Результати проведеного дослідження відображено у табл. 1.

Табл. 1. Категорійна класифікація витрат*

\begin{tabular}{|c|c|c|c|c|}
\hline $\begin{array}{l}\text { № } \\
\text { 3/ח }\end{array}$ & $\begin{array}{l}\text { Катего- } \\
\text { рія }\end{array}$ & Ознака & Види витрат & $\begin{array}{l}\text { Частка ав- } \\
\text { торів, \%* }\end{array}$ \\
\hline 1 & $\begin{array}{l}\text { "Індиві- } \\
\text { дуаль- } \\
\text { ність" }\end{array}$ & $\begin{array}{c}\text { за способом } \\
\text { включення до } \\
\text { собівартості }\end{array}$ & прямі, непрямі & 100 \\
\hline \multirow[b]{2}{*}{2} & \multirow{2}{*}{$\begin{array}{l}\text { "Мате- } \\
\text { рія" }\end{array}$} & \multirow[b]{2}{*}{$\begin{array}{c}\text { за економічним } \\
\text { змістом }\end{array}$} & елементи витрат & 78,5 \\
\hline & & & $\begin{array}{c}\text { статті калькулю- } \\
\text { вання }\end{array}$ & 64 \\
\hline 3 & $\begin{array}{l}\text { "Енер- } \\
\text { гія" }\end{array}$ & $\begin{array}{c}\text { за відношенням } \\
\text { до обсягів ви- } \\
\text { робництва }\end{array}$ & $\begin{array}{l}\text { умовно-постійні } \\
\text { умовно-змінні }\end{array}$ & 100 \\
\hline 4 & $\begin{array}{l}\text { "Прос- } \\
\text { тip" }\end{array}$ & $\begin{array}{c}\text { за місцем ви- } \\
\text { никнення }\end{array}$ & $\begin{array}{l}\text { цехів, дільниць, } \\
\text { переділів }\end{array}$ & 14 \\
\hline 5 & "Час" & $\begin{array}{c}\text { за календарним } \\
\text { періодом }\end{array}$ & $\begin{array}{c}\text { поточні, однора- } \\
\text { зові }\end{array}$ & 21 \\
\hline
\end{tabular}

Примітка: * складено на основі власних досліджень автора; \%* - котрі підтримують потребу розподілу на зазначені види витрат.

Під час дослідження ми оптимізували існуючу класифікацію витрат. На наш погляд, для ефективного використання елементів системи управління витратами, а саме: планування, нормування, калькулювання, регулювання, контролю та аналізу в розрізі об'єктів обліку витрат, необхідним є одночасне комбінування декількох категорій класифікації, яке можливе тільки під час поєднання їх у багатовимірній площині. Втілення наведеного вище повинно базуватися принципово на нових засадах використання запропонованої категоріальної класифікації витрат із застосуванням новітніх технологій, що одночасно врахують потреби бухгалтерського та управлінського обліку, дасть змогу скоротити час оброблення інформації, підвищить оперативність прийняття управлінських рішень та сприятиме покращенню системи управління витратами суб'єктів економіки.

Для реалізації наведеного вище на базі запропонованої категоріальної класифікації витрат ми розробили тривимірну матричну модель класифікації витрат, зразок якої зображено на рис. 8 .

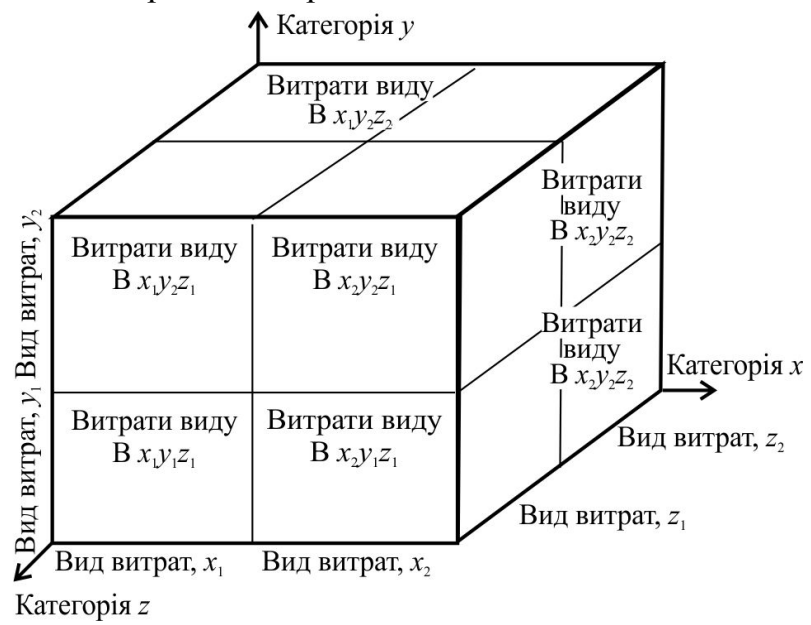

Рис. 8. Тривимірна матрична модель класифікації витрат
Суть матричної моделі класифікації полягає в одночасному розподілі витрат за трьома різними категоріями, обраними залежно від поставлених цілей. Для цього ми використали декартову ортогональну систему координат, де осі $x, y, z$ - відповідають певним категоріям. При цьому базовою, на наш погляд, повинна бути категорія $x$ - "матерія", що відображає склад витрат. Дві інші категорії характеризують кожну складову витрат із двох, непов'язаних між собою, сторін. Матриця набуває вигляду паралелепіпеда, поділеного на $i$-ту кількість кубів (елементів матриці). Положення куба задається трьома ознаками за перпендикулярною проекцією куба на ортогональні осі $x, y$, та $z$, у проміжки певних трьох видів витрат, за якими куб відповідатиме характеристикам одночасно бухгалтерського та управлінського обліку, що задані змінною з трьома індексами $B_{x, y, z}$. Матриця виступає у ролі тривимірної таблиці, в кожний куб якої вводиться певна сума витрат, що належить до певного виду кожної категорії та, в підсумку, граф і стовбці свідчать про загальну суму витрат цього виду.

Сума витрат усіх видів однієї категорії дорівнює сумі витрат іншої категорії. Контрольною є загальна сума всіх елементів матриці, що визначається за формулою:

$$
S=\sum_{B=1}^{n} B_{x_{n} y_{n} z_{n}}
$$

де: $B$ - вид витрат; $n$ - кількість елементів матриці; $x, y$, $z$ - категорії розподілу.

Наведена вище тривимірна матрична класифікація витрат, розроблена на базі категоріальної класифікації, може застосовуватись для будь якого суб'єкта господарювання з урахуванням галузевих особливостей та конкретних цілей управління. Перевага цієї моделі полягає в узгодженості всіх видів витрат і класифікаційних ознак управлінського та бухгалтерського обліку, а також у встановленні взаємозв'язків та взаємозалежностей між ними (Davydovych, 2008; Palyi, 1987).

По-перше, вкрай важливим є вирішення проблеми обгрунтованого розподілу витрат на прямі й непрямі, оскільки від нього залежить правильність віднесення витрат на відповідний об'єкт калькулювання, а відтак і достовірність визначення собівартості продукції, робіт, послуг. Для вирішення цієї проблеми необхідним є застосування одночасного розподілу витрат у категоріях "Матерія", "Простір" та "Індивідуальність".

Другою проблемою управління витратами суб'єктів економіки, що постає сьогодні, є відсутність дослідження поведінки витрат. Вирішення цієї проблеми базується на дослідженні витрат у межах тривимірного розподілу їх за категоріями "Матерія", "Енергія" та "Простір".

Розподіл витрат за категорією "Енергія" на постійні та змінні з врахуванням ї складу та місць виникнення відіграє важливу роль під час здійснення антикризового управління, оскільки дослідження поведінки витрат у цьому ракурсі дає змогу розрахувати мінімальний розмір витрат, що складуть виробничу собівартість, яка буде базою для розрахунку критично допустимого зниження ціни продукції, товарів, робіт, послуг суб'єктів господарювання. У разі настання кризової ситуації продовження їх роботи навіть за умови встановлення ціни в розмірі, нижчому від повної собівартості (за умови дотримання розрахованого критично допустимого рівня 
зниження ціни), призведе практично до таких самих збитків, як зупинка виробничого процесу, але в цьому випадку підприємство не втратить своєї позиції на ринку.

Висновки. Обгрунтований розподіл витрат під час розрахунку собівартості дає змогу правильно віднести відповідні витрати до відповідних об'єктів калькулювання, що дає можливість аналізувати поведінку витрат (у складі собівартості того чи іншого об'єкта калькулювання) уже на стадії їх виникнення. Це свідчить про тісний взаємозв'язок наведених вище проблем, вирішення яких потребує комплексного підходу, що реалізовуватиме завдання, поставлені з обох сторін одночасно, що потребує автоматизованої системи оброблення даних та необхідного програмного забезпечення. Реалізація такого підходу можлива тільки за умови використання категоріальної багатовимірної класифікації витрат у зазначених параметрах із застосуванням OLAP технологій. OLAP - це нова інформаційна технологія, що забезпечує аналітикам, управлінцям та керівникам можливість вивчати великі об'єми взаємопов'язаних даних за допомогою швидкого інтерактивного їх відображення на різних рівнях деталізації з різних поглядів відповідно представлення кінцевого користувача про простір його діяльності. Застосування цієї технології з метою дослідження витрат дає змогу робити плоскі зрізи куба даних і повертати його потрібною гранню у будь-якому напрямку. За допомогою OLAP (аналітичного оброблення в реальному часі) будь-яку суму витрат можна охарактеризувати за приналежністю до певної статті витрат, місця виникнення, визначити прямі чи непрямі витрати, постійні чи змінні, а також розрахувати вплив їх зміни на собівартість певного об'єкта калькулювання.

Застосування запропонованої багатовимірної матричної моделі класифікації витрат у зазначених параметрах дає змогу скоротити час оброблення інформації, підвищує оперативність прийняття управлінських рішень та сприяє покращенню системи управління витратами суб'єктів економіки загалом.

\section{Перелік використаних джерел}

Atamas, P. Y. (2009). Upravlinskyi oblik. (2nd ed.). Kyiv: Tsentr uchb. Literatury, 440 p. [In Ukrainian].

Bernard, S., Chatelain, C., Adam, S., \& Sabourin, R. (2016). The Multiclass ROC Front method for cost-sensitive classification. Pattern
Recognition, 52 , $46-60$. https://doi.org/10.1016/j.patcog.2015.10.010

Bondar, N. M., Vorotin, V. Ye., Haievskyi, O. A., Kalyna, A. V. (Ed.), et al. (2006). Ekonomika pidpryiemstva. Kyiv: MAUP, 352 p. [In Ukrainian].

Butynets, F. F. (2012). Vytraty vyrobnytstva ta yikh klasyfikatsiia dlia potreb upravlinnia. Problemy teorii ta metodolohii bukhhalterskoho obliku, kontroliu i analizu, 1(22), 11-18. [In Ukrainian].

Butynets, F. F. (Ed.), Davydiuk, T. V., Kanurna, Z. V., Maliuha, N. M., \& Chyzhevska, L. V. (2005). Bukhhalterskyi upravlinskyi oblik. (3rd ed.). Zhytomyr: PP "Ruta", 480 p. [In Ukrainian].

Davydovych, I. Ye. (2008). Upravlinnia vytratamy. Kyiv: Tsentr uchbovoi literatury, 320 p. [In Ukrainian].

Dreval, O. Yu. (2008). Planuvannia diialnosti pidpryiemstva. Sumy: Vyd-vo SumDU, 146 p. [In Ukrainian].

Erukhymovych, Y. L. (2003). Tsenoobrazovanye. (3rd ed.). Kyiv: MAUP, 108 p. [In Russian].

Filina, H. I. (2008). Upravlinnia vytratamy ta tsinamy. Kyiv: Personal, 240 p. [In Ukrainian].

Horbonos, F. V., Cherevko, H. V., \& Pavlenchyk, N. F. (2010). Ekonomika pidpryiemstva. Kyiv: Znannia, 463 p. [In Ukrainian].

Ilina, S. B. (2009). Bukhhalterskyi finansovyi oblik. Retrieved from: http://b-ko.com/book 359 glava $57 \quad 15$ 1.html. [In Ukrainian].

Lyshynenko, O. V. (2009). Bukhhalterskyi upravlinskyi oblik. (2nd ed.). Kyiv: TsUL, 440 p. [In Ukrainian].

Pacholy, L. (1995). Traktat o schetakh y zapysiakh. Fynansy, uchet, audyt, 160. [In Russian].

Palyha, Ye. M. (Ed.). (2010). Ekonomika pidpryiemstva. Lviv: Ukr. akad. drukarstva, 600 p. [In Ukrainian].

Palyi, V. F. (1987). Osnovy kalkulyrovanyia. Moscow: Fynansy i statystyka, 288 p. [In Russian].

Ranhanatan, Sh. R., \& Homolytska, T. S. (1970). Klassyfykatsyia dvoetochyem. Osnovnaia klassyfykatsyia. Moscow: HPNTB SSSR, 457 p. [In Russian].

Shtelmakh, L. O. (2009). Klasyfikatsiia vytrat v upravlinskomu obliku ta aspekty upravlinnia nymy. Ekonomichni nauky / oblik $i$ audyt. Retrieved from: http://www.rusnauka.com/13 EISN 2009/Econo mics/45384.doc.htm. [In Ukrainian].

Stotskyi, V. Y. (1934). Osnovu kalkuliatsyy y ekonomycheskoho analyza sebestoymosty. Moscow-Leningrad: Sotsekhyz, 479 p. [In Russian].

Tapkan, P., Özbakır, L., Kulluk, S., \& Baykasoğlu, A. (2016). A costsensitive classification algorithm: BEE-Miner. Knowledge-Based Systems, 95, 99-113. https://doi.org/10.1016/j.knosys.2015.12.010

Teisseyre, P., Zufferey, D., \& Słomka, M. (2019). Cost-sensitive classifier chains: Selecting low-cost features in multi-label classification. Pattern Recognition, 86, 290-319. https://doi.org/10.1016/i.patcog.2018.09.012

Tkachenko, N. M. (2003). Bukhhalterskyi finansovyi oblik na pidpryiemstvakh Ukrainy. (6th ed.). Kyiv: A.S.K., 784 p. [In Ukrainian].

I. S. Stetsiv

Lviv Polytechnic National University, Lviv, Ukraine

\section{THREE-DIMENSIONAL MATRIX CLASSIFICATION MODEL OF EXPENSES OF ECONOMIC ENTITIES AS A MEANS OF ADAPTING A SCIENTIFICALLY GROUNDED APPROACH TO AUTOMATION OF MANAGERIAL PROCESSES}

Effective functioning of economic entities is dependent on the level of automation of managerial processes, although the achievements of information technology in this direction are not characterized by significant success. The process of automation of cost management as an important part of the enterprise management in general, requires improvement, in particular. The development and implementation of a high level of information technology requires the adaptation of the theoretical provisions of cost management to the algorithms of computer programs. The research is based on the principles of the dialectical method of knowledge of phenomena and processes, within which abstraction, analogy, analysis, induction, deduction, synthesis - for the streamlining of the scientific classification of costs, graphic method, design, and modeling - for a three-dimensional matrix model of cost classification are used. The analysis of literary sources has shown that scientists have described more than 40 classification criteria for grouping costs today, which should contribute to a comprehensive study of costs. However, such a variety of classification marks only complicates the process of knowledge, since the existing classification is oversaturated today by duplication of their substance and content. To solve this problem, we conducted a study of the approaches of scientists to the classification of costs, on the basis of which all existing types of costs are grouped in accordance with the general theoretical principles of the formation of classifications. For the effective use of elements of the cost management system, namely planning, valuation, calculation, regulation, control and analysis in the context of cost 
accounting objects, it is necessary to simultaneously combine several categories of classification, which is possible only when combined in a multidimensional plane. To implement the above based on the proposed categorical cost classification, we have developed a three-dimensional matrix model for cost classification. With OLAP technology, any amount of expenses can be characterized by belonging to a particular item of expenses, place of origin, determine direct or indirect costs, fixed or variables, and also calculate the effect of their change on the cost of a particular object of calculation. A three-dimensional matrix cost classification developed on the basis of categorical classification can be applied to any entity, considering industry specifics and specific management objectives, reduces the time for data processing, increases the efficiency of management decisions and contributes to improving the cost management system of economic entities.

Keywords: categorical classification; OLAP technology; cost management; cost elements; calculating articles. 